TAPROBANICA, ISSN 1800-427X. December, 2013. Vol. 05, No. 02: pp. 157-162.

(c) Taprobanica Private Limited, 146, Kendalanda, Homagama, Sri Lanka.

http://www.sljol.info/index.php/tapro

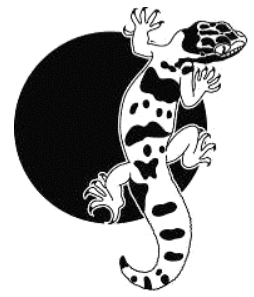

\section{Phenotype evaluation of free-ranging European mouflon}

Since introduced to Lanai in 1954 (Tomich, 1986) European mouflon have been as controversial as feral domestic sheep, sheep hybrids, and mouflon introduced to other Isands in the Hawaiian Archipelago (Hess \& Banko, 2011). To conservationists concerned with the impacts to native flora and fauna European mouflon are an introduced ungulate pest that needs to be eliminated to avoid degradation of the native environment and indigenous wild species (Hess \& Banko, 2011). On the other hand European mouflon are considered a highly valued species for recreational and trophy hunting (Frisina \& Frisina, 2005) and in some locations, like Lanai, are important economically in a difficult economy. Many residents of Lanai value the recreational hunting of mouflon on the 14,000 ha Lanai public game management area (HDNRC, 2010). Mouflon also are an appreciated source of protein to some residents of Lanai. Providing locals with a recreational source of meat was one of the reasons for introducing mouflon (Lepczyk et al., 2011). While controversial, mouflon have a strong contingent that advocates for their existence. Because the mouflon on Lanai are free ranging with no fenced populations, trophy hunters consider the Lanai mouflon a potential source of "phenotypically true" sheep suitable for inclusion in many different trophy records. As a result, in October 2011 we surveyed mouflon to determine if the Lanai population exhibited the physical characteristics typical of European mouflon as reported in the literature.

According to Tomich (1969), Giffen (19751979), Tomich (1986) and others, the Hawaiian Islands support true European mouflon and feral sheep-mouflon crosses, a situation similar to many locations on the U.S. mainland and throughout Europe. Due to intentional removal, however, there have not been domestic sheep, mouflon-domestic sheep crosses, feral goats, or feral pigs on Lanai for more than 30 years. European mouflon will readily cross with domestic sheep and will produce fertile offspring (Tomiczek, 1985; Mitchell \& Frisina, 2007). Thus, the question of how "true" to the phenotype various hunted populations are is often raised by hunters and hunter-conservation organizations.

European Mouflon: European mouflon are native to the Mediterranean islands of Corsica and Sardinia, and also Cyprus where a slightly different phenotype occurs. Mouflon are widely distributed due to introductions to the Crimea, Germany, Switzerland, Holland, Luxemburg, Italy, Poland, the Czech Republic, Slovakia, Hungary, Yugoslavia, Romania, Spain, Finland, Denmark, Bulgaria, and the United States (Clark, 1964; Uloth, 1976; Valdez, 1982; Mitchell \& Frisina, 2007). Most mouflon populations in Europe were established during the past 250 years (Tomiczek, 1985; Uloth \& Prien, 1985). According to Valdez (1982), "The European and Cyprian mouflon probably originated from feral (domestic gone wild) primitive domestic sheep established on the islands of Corsica, Sardinia, and Cyprus by man." Some reports indicate the mouflon on Corsica have interbred with domestic sheep brought to the island and domestic strains were added to European introductions to provide hunters with larger trophies (Mungall \& Sheffield, 1994). Mouflon are considered very similar to domestic sheep and may be very similar to those wild sheep originally domesticated by man. Blood analyses reported by Stralit \& Bobbak (1988) provide further evidence of similarity between domestic sheep and mouflon. In a report on a study of hemoglobin phenotypes in wild European mouflon on the island of Sardinia, Naritana et al. (1990) concluded there were structural and physiological homologies between domestic 
Sardinian sheep and mouflon specific $\beta$-globin alleles.

Hadjisterkotis (1996), in reporting on the taxonomy of mouflon on the Greek island of Cyprus, indicated that these sheep on Cyprus stem from a domesticated wild strain of sheep introduced by man around 6000 BC. From analysis for cytochrome $b$ gene in mitochondrial DNA, Arai et al. (1997) concluded that domestic sheep have been established from mouflon. This close association of European mouflon with domestic sheep on both native and introduced ranges has long made their classification problematic. For the aforementioned reasons recently published taxonomies exclude the European mouflon from the wild sheep species, considering them to be a very early feral form of domestic sheep (ICZN, 2003; Groves \& Grubb, 2011; Grubb, 2005; Valdez, 2011). Despite this zoological consensus, the classification of European mouflon will likely continue to be controversial because of their value to hunters as a wild big game animal.

Because of their origins and close relationship to mainland moufloniforms, Valdez (1982) considered insular Mediterranean mouflon to be conspecific with mainland forms. $\mathrm{He}$ recognized mouflon dwelling on Corsica and Sardinia as a different subspecies from those on Cyprus. Cugnasse (1994) classified the mouflon on the Mediterranean islands of Corsica, Sardinia, and Cyprus as three different varieties. Other authors have proposed different classification schemes. Due to varying opinions on European mouflon taxonomic status, we avoided the use of scientific names in this paper.

Because of their similarity to domestic sheep there is no readily defined DNA profile unique to the European mouflon; therefore, we based our analysis on observable morphological characteristics reported in the literature as typical of "true" mouflon.

Study Area: Wild mouflon range freely over the privately owned Island of Lanai, which is about 141 sq. mi. in area. Lanai is within the Hawaiian Archipelago located between $18^{\circ}-22^{\circ}$ $\mathrm{N}$ in the central Pacific Ocean (Delorme, 1999) and lies within a rain shadow created by the neighboring Islands of Maui and Molokai. As a result much of the island at lower elevations is arid with shrub-grass plant communities grading into forest habitats at higher elevations. At lower elevations red volcanic soils and sparse vegetation are typical. The vegetation of Lanai is complex with much alteration ongoing due to anthropogenic alteration of the environment and introduction of many exotic species (Cuddihy \& Stone, 1990). Two introduced species of large wild ungulates inhabit Lanai-the European mouflon and axis deer (Axis axis). Tomich (1986) provides a synthesis of information in which he indicates mouflon were first introduced to Lanai in 1954 with subsequent releases including the introduction of 28 animals.

Mouflon were observed in the field for characteristics of European mouflon reported by Lydekker (1901), Lydekker (1912), Clark (1964), Uloth (1976), Valdez (1982), Mungal \& Sheffield (1994), Pierget \& Uloth (2005), Mitchell \& Frisina (2007), and others. Clark (1964) described the European mouflon with its distinctive coloration as "...by far the bestdressed of all Moufloniformes, if not the best dressed of all the wild sheep of the world." By direct observation we looked for characteristics both atypical and typical of "true" European mouflon. For rams, typical characteristics include: hair is close, thick, and somewhat stiff; coarse hair rather than wool forms the outer coat; a distinct neck ruff on mature rams during the rut; general color of the coat on mature rams rufous brown or foxy red shading into chocolate brown on the head and face; black on sides of the neck, throat, chest with a band of black on the flanks; black also as a streak down the withers, on the outer front surfaces of the forelegs above the knees, and on the front and outer sides of the hind limbs above the hocks; ears grayish with the margins and part of their interior white; muzzle and chin grayish white shading into grayish rufous in the middle of the black area on the throat; a broad band grizzled with white defining the rear border of the saddle patch; the buttocks and all under parts, except for a narrow streak down the forelegs, white; limbs exhibiting a streak of white on their back surface above the knees and hocks; below the knees, legs white except for a varying amount of black on the front of the anterior pair. In winter coat the general color of the upper parts deepens and becomes more of a chestnut brown. The saddle patch on each side 
of the body lightens until in many older rams is nearly white. Horns of mouflon are variable but most typically are curved inward at about the $3 / 4$ curl point. A strong sexual dimorphism exists, especially in older animals. The pelage coloration exhibited by "true" female mouflon varies from light tan to dark brown. The dorsal patch is absent or indistinct. Lambs are similar in appearance to ewes. Adult females may or may not have horns. When horns are present on females they are only a few inches in length.

Binoculars (10X) and spotting scope (15X40) were used to make field observations. Only sheep within a few hundred yards and observed under good lighting conditions were included in the sample. Particular attention was paid to spotting atypical features.

Data were recorded and averages calculated and compared with lengths reported for mouflon in the literature. All measurements were recorded to the nearest 1/8 inch. Each ram was assigned an approximate age using the annular growth ring ageing technique (Geist 1966). Lanai's year round growing season resulted in some growth rings being indistinct.

Visual observations and physical measurements, compared with similar information reported by Lydekker (1901), Clark (1964), Uloth (1976), Valdez (1982), Mungal \& Sheffield (1994), Piegert \& Uloth (2005), Mitchell \& Frisina (2007), and others, formed the basis for an opinion as to the phenotype status of Lanai mouflon.

From October $28^{\text {th }}$ through November $4^{\text {th }} 521$ free-ranging wild mouflon were observed. Our sample of live animals was composed of all age classes and both sexes (Fig. 1). Additionally, horn measurements were taken from 10 mouflon rams (hunter trophies and picked-up heads) and tail length measured for 9 hunter harvested rams (Table 1). Measurements are within the range for Hawaiian mouflon reported by Frisina \& Frisina (2000).

Population: The proportion of the population sampled is not known, as no recent population estimate of total mouflon numbers is available for the entire Lanai mouflon range. A fall survey of the Lanai Cooperative Game Management Area (LCGA) in 2010 yielded a population estimate of 2,039 mouflon. The
LCGA does not include the entire mouflon range. The landform exhibits rugged topography at higher elevations grading to low ridges and plains at lower elevations near the ocean. Most of the vegetation consists of forest, shrubland and small meadows. All mouflon on Lanai are free-ranging with none held behind wildlife-tight fence. Most of the mouflon range bounds the Pacific Ocean and all public and private hunting areas are free of high fence. The difficulty of making accurate population estimates in such habitats is well known. Therefore, since sheep were obviously abundant (average of 80 sheep observed per field day), sampling effort concentrated on observing the maximum number of animals possible rather than a predetermined sample size. We had no way of knowing how many mouflon were observed more than once, so each day we traveled to different portions of the range.

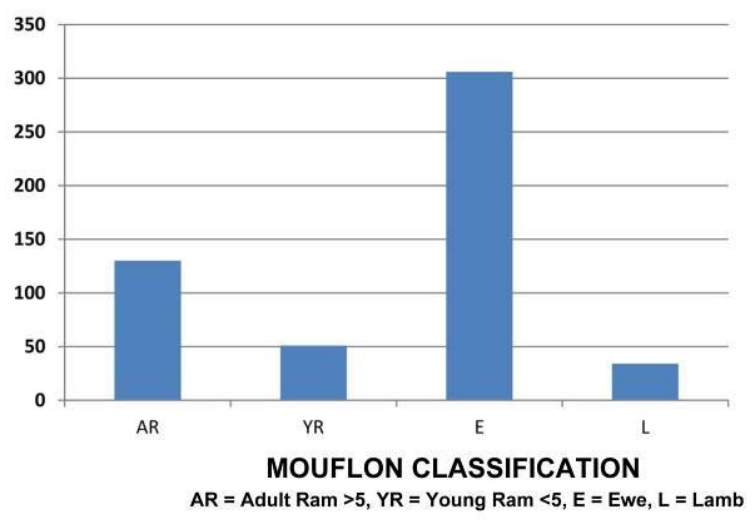

Figure 1: Age structure of mouflon observed on Lanai.

Visual Characteristics: All of the 521 mouflon observed exhibited coat coloration patterns and other physical characteristics described for true mouflon by the authors previously referenced. All adult rams exhibited pelage typical of the rutting season (Figs. $2 \& 3$ ).

Physical Characteristics: Horn measurements were collected from 10 rams ranging in age from 4 to 11 years (Table 1). The mean age for rams sampled was 8 years. Mean horn length was 76.4 and $77 \mathrm{~cm}$ for the right and left sides, respectively. Mean horn basal circumference was 24.4 and $24.2 \mathrm{~cm}$ for the right and left sides, respectively. These measurements are slightly larger than similar measurements reported by Frisina \& Frisina (2000) for European mouflon on the island of Hawaii. The 
aforementioned measurements are within the ranges reported by Clark (1964), Uloth (1976), Valdez (1982), Mungal \& Sheffield (1994), Frisina \& Frisina (2000), Piegert \& Uloth (2005), and Mitchell \& Frisina (2007). Typically, horns of mature (trophy type) rams were observed to arc in rather than out at the horn tips.

Table 1: Horn measurements for 10 adult rams from Lanai, Hawaii

\begin{tabular}{|c|c|c|c|c|c|}
\hline \multirow[t]{2}{*}{ No. } & \multicolumn{2}{|c|}{ Horn length $(\mathrm{cm})$} & \multicolumn{2}{|c|}{$\begin{array}{c}\text { Basal Circum. } \\
(\mathrm{cm})\end{array}$} & \multirow[t]{2}{*}{ Age } \\
\hline & Right & Left & Right & Left & \\
\hline 1 & 73 & 76.2 & 26 & 25.4 & 8 \\
\hline 2 & 81.6 & 84.1 & 24.8 & 24.1 & 9 \\
\hline 3 & 77.2 & 75.6 & 24.1 & 24.5 & 6 \\
\hline 4 & 87 & 86 & 25.4 & 25.4 & 10 \\
\hline 5 & 80.7 & 81.6 & 24.5 & 24.1 & 9 \\
\hline 6 & 80.7 & 81.6 & 22.2 & 22.9 & 11 \\
\hline 7 & 88.9 & 82.6 & 25.7 & 25.7 & 8 \\
\hline 8 & 59.7 & 64.1 & 23.8 & 24.1 & 4 \\
\hline 9 & 74 & 76.2 & 21.3 & 22.2 & 9 \\
\hline 10 & 61.6 & 61.6 & 25.4 & 23.5 & 6 \\
\hline Mean & 76.4 & 77 & 24.4 & 24.2 & 8 \\
\hline
\end{tabular}

True European mouflon have a "short deer-like tail, with twelve vertebrae in the interior" (Lydekker, 1912). Tail length is an important indicator of how "true" to the phenotype a population of mouflon are; in domesticated breeds the tail becomes more or less elongated (Lydekker, 1912). The long tail of most domestic sheep breeds is a product of breeding for domestic forms (Lydekker, 1898). The tail length (to the tip of hair) was measured for 9 hunter harvested Lanai mouflon rams in 2011 and the mean length was $12 \mathrm{~cm}$ (range 11.4$12.4 \mathrm{~cm}, \mathrm{SD}=0.3167)$. Not including the tail hair would have reduced the mean length by about $1.9 \mathrm{~cm}$. In any event, all tails were short and "deer-like" fitting the phenotype of a "true" European mouflon (Figs. $2 \& 3$ ).

Wild free-ranging mouflon inhabiting the island of Lanai are "true" European mouflon, exhibiting all of the typical or classic characteristics attributed to this old-established feral stock.

\section{Acknowledgements}

We thank P. Fisher, Hawaii Safaris for funding and assisting with travel arrangements. ALHWI, Inc.; GSCO; and MSU-Bozeman, ARNR, also cooperated. We also appreciated S. Gelokoski for sharing his intimate knowledge of wildlife resources on Lanai, and D. Campbell for his enduring commitment to wild sheep conservation. We are grateful to $\mathrm{H}$. and Z. Brown and the Fisher family for their friendship and hospitality.

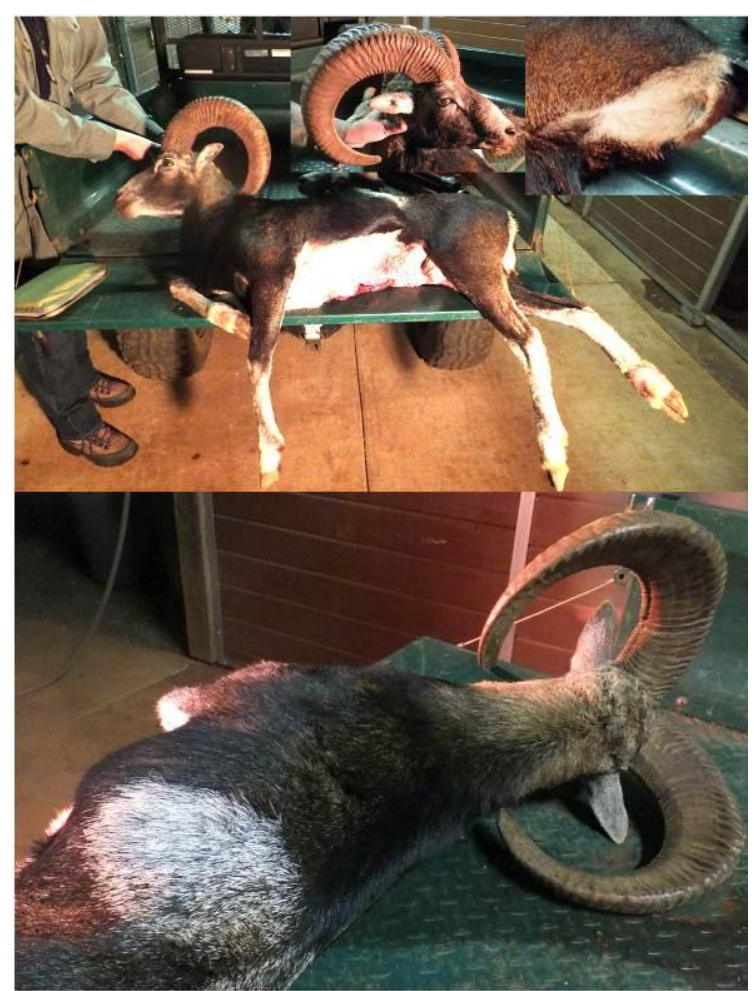

Figure 2: A typical mature ram from Lanai. Note the short "deer-like" tail (4.5 in), slight tendency of the horns to curve inward, white saddle patch-rump patch-underbelly-lower legs, and grayish nondrooping ears.

\section{Literature Cited}

Arai, K., I. Muncechika, II Ito, A. Kikkawa, T. Kanazawa, and M. Losu Giyama, 1997. Phylogenetic relationship of Caprini estimated by Cytochrome b gene sequence analysis. Animmal Science Technology, 68: 148-155.

Clark, J. L., 1964. The great arc of the wild sheep. University of Oklahoma Press. Norman: 247.

Cugnasse, J. M., 1994. Revision taxinomique des mouflons des iles mediterraneenes. Mammalia Tome. 58, N3: 507-512.

Cuddihy, L. W. and C. P. Stone, 1990. Alteration of native Hawaiian vegetation. University of Hawaii Press. Honolulu, HI: 138.

Delorme, 1999. Hawaii atlas and gazeteer. Delorme. Yarmouth, ME: 64. 
Frisina, M. R. and R.M. Frisina, 2000. Phenotype evaluation of free ranging European mouflon (Ovis orientalis musimon) on Kahuku Ranch, South Point Hawaii. Northern Wild Sheep and Goat Council Addendum to the Proceedings of the Eleventh Biennial Symposium: 27.

Frisina, M. R. and R. M. Frisina, 2005. Mouflon Misnomer. Wild Sheep, Summer: 54-57

Geist, V., 1966. Validity of horn segment counts in aging bighorn sheep. Journal of Wildlife Management, 30: 634-635.

Giffen, J. G., 1975-1979. Ecology of mouflon sheep on Mauna Kea, Pittman Robertson Project No. W-17-R, Study No. R-11, State of Hawaii Department of Land and Natural Resources Division of Forestry and Wildlife: 65.

Groves, C. and P. Grubb, 2011. Ungulate Taxonomy. John Hopkins University Press. Baltimore, MD: 317.

Grubb, P., 2005. Order Artiodactyla. Pp. 637722, In: D. E. Wilson and D. Reeder (eds.). Mammal species of the world, a taxonomic and geographic reference. Third edition, Vol. 1. John Hopkins University Press, Baltimore, USA: 743.

Hadjisterkotis, V. E., 1996. Herkunft, taxonomic and neuere Entwicklung des Zyprischen mouflons (Ovis gmelini ophion). Zeitschrift fuer Jagdwissenschaft, 42: 104-110.

HDNRC (Hawaii Department of Natural Resources and Conservation), 2010. 2010 game mammal survey of the Lanai Cooperative Game Management Area. Unpublished report: 5.

Hess, S. C. and P. C. Banko, 2011. Sheep vs. palila on Mauna Kea. Wildlife Professional, 5: 60-63

ICZN (International Commission on Zoological Nomenclature), 2003. Opinion 2027. 2003. Case 3010: usage of 17 specific names was based on wild species which are pre-dated or contemporary with those based on domestic animals (Lepidoptera, Osteichthyes, Mammalia); conserved. Bulletin of Zoological Nomenclature, 60: 81-84.

Lydekker, R., 1898. Wild oxen, sheep and goats of all lands. Rowland Ward, London: 318.
Lydekker, R., 1901. The great and small game of Europe, western and northern Asia and America. Rowland Ward, London: 445.

Lydekker, R., 1912. The sheep and its cousins. George Allen \& Company, Ltd. Ballantyne Press. Edinburgh, UK: 315.

Lepczyk, C. A., S. Hess, and E. D. Johnson, 2011. Is the model a misfit in Hawaii? The Wildlife Professional, 5: 64-66.

Mitchell, R. M. and M. R. Frisina, 2007. From the Himalayas to the Rockies. Retracing the Great Arc of wild sheep. Safari Press Inc. Long Beach, CA: 230

Mungall, C. E. and W. J. Sheffield, 1994. Exotics on the range. The Texas example. Texas A\&M University Press, College Station: 265.

Naitana, S., S. Ledd, E. Cocco, L. Manca, and B. Masala, 1990. Haemoglobin phenotypes of the wild European mouflon sheep living on the island of Sardinia. Animal Genetics, 21: 67-75.

Piegert, H. and W. Uloth, 2005. Der Europäische mufflon. Edition natur life, Germany: 277.

Stralit, A. and P. Bobak, 1988. Comparison of biochemical polymorphisms in mouflon and sheep: isoelectric differences in haemoglobins and quanitative variation of mouflon haemopexin. Comparative Biochemistry and Physioogy, 90B, No. 1: 159-162.

Tomich, P. Q., 1969. Mammals in Hawaii, a synopsis and national bibliography. First edition. Bishop Museum Press. Honolulu, HI: 238.

Tomich, P. Q., 1986. Mammals in Hawaii. A synopsis and national bibliography. Second edition. Bishop Museum Press. Honolulu, HI: 375 .

Tomiczek, H., 1985. The muflon (Ovis ammon musimon Schreber, 1782) In the southern and western countries of Europe. Pp. 127-133. In: Hoefs, M. (ed.). Northern Wild Sheep and Goat Council special report, wild sheep distribution, abundance, management and conservation of the sheep of the world and closely related mountain ungulates, Yukon Wildlife Branch, Whitehorse, Canada: 218

Uloth, W., 1976. Das Muffelwild. A. Ziemsen Wittenberg Lutherstadt. 
Uloth, W. and S. Prien, 1985. The history of introductions of mouflon sheep (ovis ammon musimon Schreber 1782) in central and eastern Europe and the development and management of these wild sheep populations. Pp. 133-137. In: Hoefs, M. (ed.). Northern Wild Sheep and Goat Council special report, wild sheep distribution, abundance, management and conservation of the sheep of the world and closely related mountain ungulates, Yukon Wildlife Branch, Whitehorse, Canada: 218.

Valdez, R., 1982. The wild sheep of the world. Wild Sheep and Goat International. Mesilla, NM: 186.

Valdez, R., 2011. Genus Ovis. Pp. 727-739. In: Wilson, D. E. and R. A. Mittermeier (eds.). The mammals of the world, hoofed mammals, Vol 2. Lynx Edicions, Barcelona, Spain.
Submitted: 8 July 2012, Accepted: 22 Nov. 2013 Sectional Editor: Colin P. Groves

M. R. Frisina ${ }^{1}$ \& R. M. Frisina ${ }^{2}$

${ }^{1}$ Department of Animal \& Range Sciences, Room 212 Animal Biosciences Building, Montana State University Campus, Bozeman, MT. 59715, USA E-mail: mike.frisina @montana.edu

${ }^{2}$ August L. Hormay Wildlands Institute, Inc., PO Box 4712, Butte MT. 590702, USA
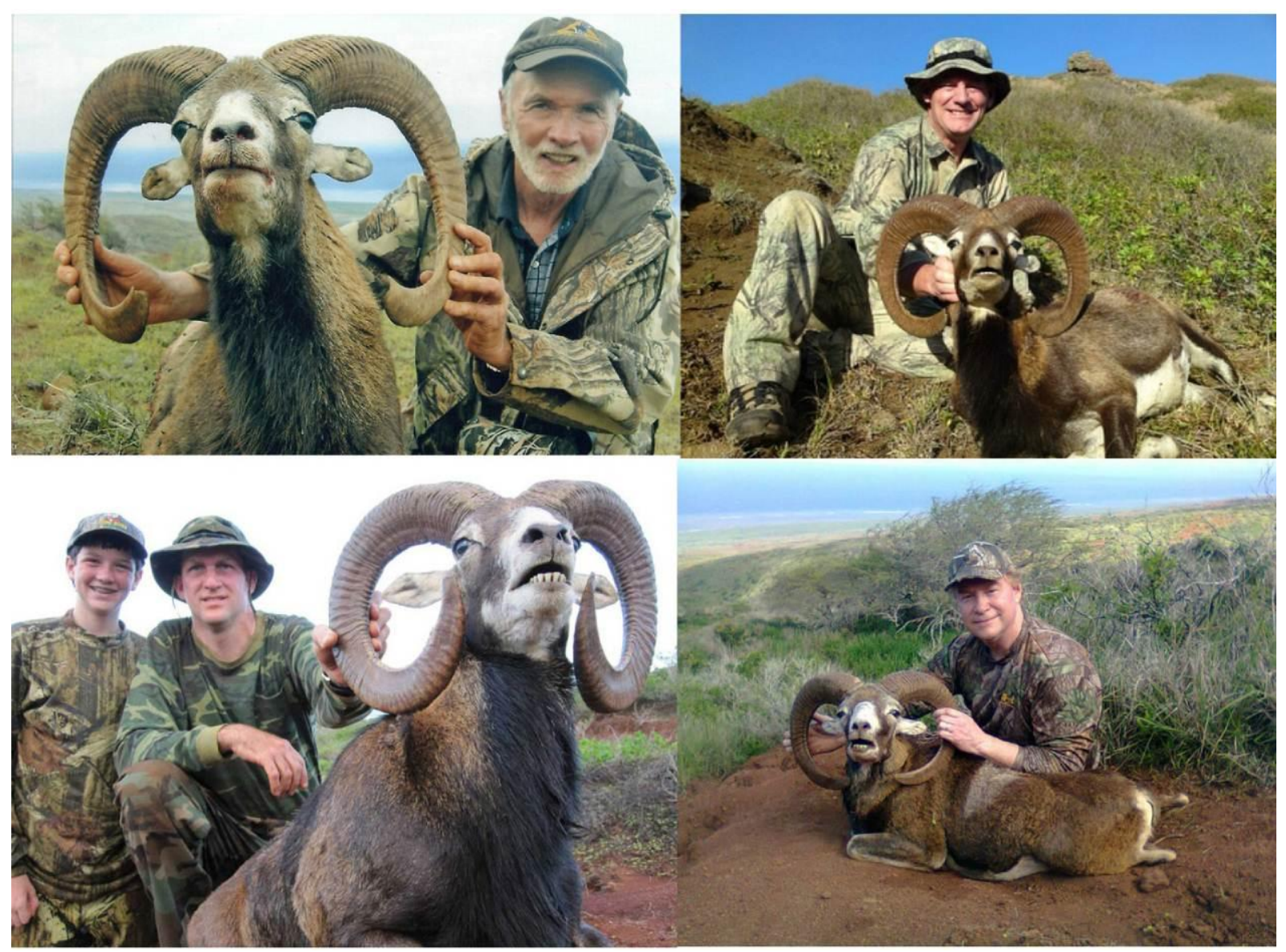

Figure 3: Lanai mouflon ram trophies. 